\title{
Malformations, withdrawal manifestations, and hypoglycaemia after exposure to valproate in utero
}

\author{
E Thisted, F Ebbesen
}

\begin{abstract}
An unselected series is presented of 17 infants born to epileptic mothers and exposed to sodium valproate during pregnancy. Nine infants had minor abnormalities and of these infants five also had major malformations, described as the 'fetal valproate syndrome'. The most frequent malformation was congenital heart disease. Nine of the infants had manifestations of withdrawal, such as irritability, jitteriness, abnormalities of tone, seizures, and feeding problems. Four of these infants had an unrelated hypoglycaemia. The frequency of withdrawal symptoms was significantly related to the dose of valproate given to the mothers in the third trimester, and there was a tendency for both the frequency of the minor abnormalities and the major malformations to be related to the valproate dosage in the first trimester. (Arch Dis Child 1993; 69: 288-291)
\end{abstract}

The frequency of minor abnormalities and major malformations in infants of epileptic mothers is increased and associated with the epilepsy. ${ }^{1}$ In addition, phenytoin given to pregnant women might increase the frequency of abnormalities and malformations, 'the fetal hydantoin syndrome'. ${ }^{2}$ Other antiepileptic drugs are suspected of having a teratogenic effect.

The teratogenic effect of valproate was observed in animals by Pinder et $a l^{3}$ and a possible teratogenic effect has also been described in humans. ${ }^{4-18}$ It has been suggested that there is an association between valproate treatment during pregnancy and spina bifida in the fetus.5612 Furthermore, some authors have postulated the existence of a 'fetal valproate syndrome', in which infants have minor abnormalities and major malformations to a variable degree. ${ }^{9} 141518$

We present 17 infants born to 17 epileptic mothers who received sodium valproate as monotherapy or polytherapy during pregnancy. The purpose of this study is to draw attention to the high frequency of minor abnormalities and major malformations, the withdrawal manifestations, and hypoglycaemia in these infants.

\section{Patients and methods}

We studied all infants born to epileptic mothers treated with valproate as monotherapy or polytherapy during pregnancy in the North Jutland region of Denmark between 1 January 1987 and 31 December 1989. During this period 18000 infants were born.

Seventeen mothers gave birth to 17 infants. Twelve mothers had primary generalised epilepsy and five complex partial epilepsy (table 1). Eleven mothers had valproate as monotherapy, three had valproate and carbamazepine, two valproate and ethosuximide, and one valproate and primidone (table 1). Pregnant epileptic women were seen monthly by a neurologist. The drug plasma concentrations were measured and future doses prescribed. Doses were titrated from prepregnancy plasma concentrations to maintain a constant valproate concentration and to ensure, as far as possible, absence of seizures. Concentrations were measured as fasting

Table 1 Maternal data

\begin{tabular}{|c|c|c|c|c|c|c|c|}
\hline \multirow{2}{*}{$\begin{array}{l}\text { Mother } \\
\text { No }\end{array}$} & \multirow{2}{*}{$\begin{array}{l}\text { Type of } \\
\text { epilepsy }\end{array}$} & \multirow{2}{*}{$\begin{array}{l}\text { Epileptic } \\
\text { attack } \\
\text { during } \\
\text { pregnancy }\end{array}$} & \multirow[b]{2}{*}{ Medication } & \multicolumn{2}{|c|}{$\begin{array}{l}\text { Daily dose of antiepileptic drug(s) in } \mathrm{g} / 24 \text { hours } \\
\text { (range of plasma concentrations in } \mu \mathrm{mol} / \mathrm{h} \text { ) }\end{array}$} & \multirow[b]{2}{*}{$3 r d$ trimester } & \multirow{2}{*}{$\begin{array}{l}\text { Poor } \\
\text { compliance }\end{array}$} \\
\hline & & & & 1 st trimester & 2nd trimester & & \\
\hline 1 & Complex partial & & Valproate & $0 \cdot 0$ & $0.6 \cdot 0.9(266-360)$ & $0.9(326-347$ & \\
\hline 2 & Primary generalised & & Valproate & $0.9(159)$ & $1 \cdot 2(232-271)$ & $1 \cdot 2(256-338)$ & \\
\hline 3 & Primary generalised & & Valproate & $0.9(289)$ & $0 \cdot 9 \rightarrow 1 \cdot 2(246-384)$ & $1 \cdot 2(270-343)$ & \\
\hline 4 & Primary generalised & & Valproate & $1 \cdot 0(467)$ & $1 \cdot 0$ & $1.0(67)$ & + \\
\hline 5 & Primary generalised & + & Valproate & $1 \cdot 0(123-361)$ & $1 \cdot 0(157-238)$ & $1 \cdot 0(154-200)$ & \\
\hline 6 & Primary generalised & & Valproate & $1 \cdot 2$ & $1.2(217)$ & $1 \cdot 2(221-244)$ & \\
\hline 7 & Primary generalised & & Valproate & 1.5 & $1.5+2.5(329-581)$ & $2.5+3.0(351-426)$ & \\
\hline 8 & Primary generalised & + & Valproate & $2 \cdot 0$ & $2 \cdot 0+2 \cdot 5(33-115)$ & $3 \cdot 0(119-201)$ & + \\
\hline 9 & Complex partial & & Valproate & $2 \cdot 0(550)$ & $2 \cdot 0 \rightarrow 2 \cdot 5(252-513)$ & $2.5(301-373)$ & \\
\hline 10 & Complex partial & + & Valproate & $2.5(498)$ & $2.5 \rightarrow 3.5(495-821)$ & $4 \cdot 0 \rightarrow 5 \cdot 0(468-580)$ & \\
\hline 11 & Primary generalised & & Valproate & $3 \cdot 5(792-1132)$ & $3.5(523-692)$ & $3 \cdot 5(443-520)$ & \\
\hline 12 & Primary generalised & & $\begin{array}{l}\text { Valproate, } \\
\text { carbamazepine }\end{array}$ & $\begin{array}{l}1.0(283-519) \\
0.4 \rightarrow 0.3(22)\end{array}$ & $\begin{array}{l}1.5 \rightarrow 2.0(327-717) \\
0.2 \rightarrow 0.0\end{array}$ & $\begin{array}{l}2 \cdot 0(452-556) \\
0 \cdot 0\end{array}$ & \\
\hline 13 & Complex partial & & $\begin{array}{l}\text { Valproate, } \\
\text { carbamazepine }\end{array}$ & $\begin{array}{l}1 \cdot 0(275) \\
0 \cdot 8(25)\end{array}$ & $\begin{array}{l}1.0(307-309) \\
0.8(17-25)\end{array}$ & $\begin{array}{l}1.5+2.0(222-372) \\
1.2 \cdot 1.6(18-19)\end{array}$ & \\
\hline 14 & Complex partial & + & $\begin{array}{l}\text { Valproate, } \\
\text { carbamazepine }\end{array}$ & $\begin{array}{l}2 \cdot 7(249) \\
0 \cdot 8(22-25)\end{array}$ & $\begin{array}{l}2 \cdot 7 \rightarrow 3 \cdot 3(216-290) \\
1 \cdot 2 \rightarrow 1 \cdot 6(17-20)\end{array}$ & $\begin{array}{l}3 \cdot 3 \rightarrow 4 \cdot 2(141-481) \\
2 \cdot 2 \rightarrow 3 \cdot 2(20-29)\end{array}$ & + \\
\hline 15 & Primary generalised & + & $\begin{array}{l}\text { Valproate, } \\
\text { ethosuximide }\end{array}$ & $\begin{array}{l}3 \cdot 0(386) \\
1.0\end{array}$ & $\begin{array}{l}3 \cdot 6 \rightarrow 4 \cdot 8(372-468) \\
1.0(185-260)\end{array}$ & $\begin{array}{l}5 \cdot 4 \rightarrow 6.0(383-599) \\
1 \cdot 0(234-295)\end{array}$ & + \\
\hline 16 & Primary generalised & & $\begin{array}{l}\text { Valproate, } \\
\text { ethosuximide }\end{array}$ & $\begin{array}{l}4 \cdot 8(408) \\
1 \cdot 0(355)\end{array}$ & $\begin{array}{l}5 \cdot 4 \rightarrow 6 \cdot 0(256-476) \\
1.0(300-310)\end{array}$ & $\begin{array}{l}6 \cdot 0 \cdot 6 \cdot 6(352-632) \\
1 \cdot 0(296-319)\end{array}$ & \\
\hline 17 & Primary generalised & & $\begin{array}{l}\text { Valproate, } \\
\text { primidone }\end{array}$ & $\begin{array}{l}2 \cdot 5(601-776) \\
0 \cdot 125\end{array}$ & $\begin{array}{l}3 \cdot 0 \cdot 3 \cdot 5(674-1162) \\
0 \cdot 125(5-10)\end{array}$ & $\begin{array}{l}3 \cdot 5 \rightarrow 4 \cdot 0(385-1140) \\
0 \cdot 125(3-6)\end{array}$ & \\
\hline
\end{tabular}




\begin{tabular}{|c|c|c|c|c|c|c|c|c|c|c|c|}
\hline $\begin{array}{l}\text { Infant } \\
\text { No }\end{array}$ & $\begin{array}{l}\text { Gestational } \\
\text { age } \\
\text { (weeks) }\end{array}$ & $\begin{array}{l}\text { Birth } \\
\text { weight } \\
\text { (g) }\end{array}$ & $\begin{array}{l}\text { Apgar } \\
\text { score } \\
1-5 \\
\text { minutes }\end{array}$ & $\begin{array}{l}\text { Admitted } \\
\text { to } \\
\text { neonatal } \\
\text { unit }\end{array}$ & Irritability & Fitteriness & Hypertonia & $\begin{array}{l}\text { Hypertonial } \\
\text { hypotonia }\end{array}$ & Seizures & $\begin{array}{l}\text { Feeding } \\
\text { problems }\end{array}$ & $\begin{array}{l}\text { Hypoglycaemia } \\
\text { (minimum } \\
\text { blood } \\
\text { glucose } \\
\text { (mmoll)) }\end{array}$ \\
\hline 1 & 41 & 3250 & $10-10$ & + & + & + & + & & & + & \\
\hline 2 & 41 & 4000 & $10-10$ & & & & & & & & \\
\hline 3 & 42 & 4020 & $10-10$ & & & & & & & & \\
\hline 4 & 37 & 3150 & $10-10$ & + & & & & & & + & \\
\hline 5 & 39 & 2500 & $10-10$ & & & & & & & & \\
\hline 6 & 39 & 3640 & $10-10$ & & & & & & & & \\
\hline 7 & 40 & 2950 & $6-10$ & + & + & + & + & & & & \\
\hline 8 & 42 & 3300 & $10-10$ & & & & & & & & \\
\hline 9 & 39 & 3500 & $8-10$ & + & + & + & + & & + & & \\
\hline 10 & 39 & 3125 & $6-9$ & + & + & + & & + & & + & 0.6 \\
\hline 11 & 38 & 3500 & $6-7$ & + & & & & & & + & \\
\hline 12 & 38 & 3900 & $10-10$ & & & & & & & & \\
\hline 13 & 42 & 4100 & $9-10$ & + & + & + & + & & + & & \\
\hline 14 & 40 & 4040 & $10-10$ & + & + & + & + & & + & & $1 \cdot 1$ \\
\hline 15 & 39 & 2760 & $10-10$ & + & + & + & & + & + & & 1.7 \\
\hline 16 & 42 & 4300 & $10-10$ & + & + & + & + & & & + & \\
\hline 17 & 40 & 2840 & $10-10$ & + & + & + & & + & & + & 1.5 \\
\hline
\end{tabular}

values at 8-10 am; valproate, carbamazepine, and ethosuximide were measured using the fluorescence polarisation immunoassay ${ }^{19}$ and primidone concentration was measured using high pressure liquid chromatography. ${ }^{20}$

All women were offered amniocentesis but it was performed in only eight cases. Concentration of $\alpha$ fetoprotein in amniotic fluid was normal as were fetal chromosomes. No therapeutic abortion was performed.

The women totally abstained from or used only small amounts of alcohol during pregnancy.

Eleven of the 17 infants (65\%) were admitted to the neonatal unit and subsequently followed up in the paediatric outpatient clinic. The remaining six infants were examined in the maternity ward by a paediatrician. These children were investigated in the clinic at the age of $1 \cdot 5-3.5$ years. All infants were examined using the motor perceptual developmental test, ${ }^{21}$ and observations made of the children's ability in concentrating, mimicry, and speech.

Statistical analysis was performed using the $\chi^{2}$ test. The level of significance was chosen at $5 \%$.

Table 3 Minor abnormalities

\begin{tabular}{|c|c|c|c|c|c|c|c|c|c|}
\hline & \multicolumn{4}{|c|}{ Infant no } & \multirow[b]{2}{*}{11} & \multirow[b]{2}{*}{13} & \multirow[b]{2}{*}{15} & \multirow[b]{2}{*}{16} & \multirow[b]{2}{*}{17} \\
\hline & 1 & 4 & 7 & 10 & & & & & \\
\hline Rough curly hair & & & & + & & & + & + & + \\
\hline Epicanthic folds & + & & + & + & + & + & & & + \\
\hline Hypertelorism & & & & + & + & + & + & + & + \\
\hline Deep groove below the lower lids & + & & + & & & & + & & \\
\hline Upturned nose & + & & + & & & + & + & + & + \\
\hline Anteverted nostrils & & & & & & + & + & & + \\
\hline Shallow philtrum & + & & + & & & + & + & + & + \\
\hline Thin upper vermillion border & & & & & & + & + & + & + \\
\hline Low set or unusually shaped ears & & + & & & & + & + & + & + \\
\hline Overlapping toes & & + & & & + & & & & \\
\hline Inguinal hernias & & & & & + & & & & + \\
\hline
\end{tabular}

\section{Results}

Mothers' data are given in table 1 . The daily valproate dose varied from $0.0 \mathrm{~g}$ to $4.8 \mathrm{~g}$ in the first trimester and from 0.9 to $6.6 \mathrm{~g}$ in the third trimester. In $13(78 \%)$ women the valproate dose needed to be increased during pregnancy to maintain a constant plasma valproate concentration. This concentration measured between zero and $1162 \mu \mathrm{mol} / \mathrm{l}$. Four mothers showed poor compliance and three of them had epileptic attack(s) during pregnancy.

Data of the infants are given in table 2. Their gestational ages and birth weights were normal, 40 (37-42) weeks and 3500 (2500-4300) g (range), respectively. The deliveries were uncomplicated and in no case was an infant significantly asphyxiated.

Eleven infants $(65 \%)$ were admitted to the neonatal unit in the first two days of life, nine because of neurological symptoms and two because of major malformations.

Nine of the infants $(53 \%)$ had minor abnormalities (table 3 ), such as rough curly hair, epicanthic folds, hypertelorism, a deep groove below the lower lids, upturned nose, anteverted nostrils, shallow philtrum, thin upper vermillion border, low set or unusually shaped ears, overlapping toes, and inguinal hernias.

Major malformations were demonstrated in five of the nine infants with minor abnormalities ( $29 \%$ of the total; table 4$)$. The most common malformation was a congenital heart defect, which was present in four.

In those cases where the mothers received a daily valproate dose of $\geqslant 2.5 \mathrm{~g}$, five out of six infants were born with minor abnormalities; additionally three of the infants had major malformations. In those cases where the mothers received less than $2.5 \mathrm{~g}$ valproate, only four out of 11 infants had minor abnormalities with additional major malformations in two.

Table 4 Major malformations

\begin{tabular}{ll}
$\begin{array}{l}\text { Infant } \\
\text { No }\end{array}$ & Malformations \\
\hline 4 & $\begin{array}{l}\text { Congenital heart defect (atrial septal defect and ventricular septal defect), radial deviation of the right hand } \\
\text { Congenital heart defect (pulmonary stenosis), bilateral cataract with suspicion of blindness, severe hearing defect }\end{array}$ \\
11 & $\begin{array}{l}\text { Congenital heart defect (Fallot's tetralogy), cheilognathopalatoschisis, perineoscrotal hypospadias, bilateral undescended } \\
\text { testes }\end{array}$ \\
13 & $\begin{array}{l}\text { Congenital heart defect (bicuspid aortic valve with mild aortic insufficiency) } \\
\text { Severe herniation of oesophagus }\end{array}$ \\
\hline
\end{tabular}


Nine $(53 \%)$ of the infants developed neurological manifestations including irritability, jitteriness, hypotonia, hypertonia (or variable tone), and feeding problems (table 2). Signs and symptoms began 12 to 48 hours after delivery, lasted from three days to four weeks and were treated with phenobarbitone. In four infants there were repeated seizures from day 2 to day 5. These infants were treated with diazepam. In all nine infants the serum calcium concentration was normal; four had hypoglycaemia during days $1-4$ (blood glucose $<1.8 \mathrm{mmol} /$; t table 2 ) but recorded signs were unrelated to the glucose concentration. Hypoglycaemia was treated with intravenous glucose infusion. In one case (number 14) the treatment was supplemented with glucagon and hydrocortisone.

Neurological symptoms were seen in eight of 11 infants born to mothers who received a daily valproate dose of $2.0 \mathrm{~g}$ or more in the third trimester, but only in one infant from six mothers who received less than $2.0 \mathrm{~g}$ valproate per day $(p=0 \cdot 03)$. On follow up at age $2 \cdot 0-3 \cdot 5$ years, one child (number 1) was found to have slight, and two children (numbers 10 and 11) severe, psychomotor retardation. No infants had cerebral palsy.

\section{Discussion}

We present an unselected series of 17 Danish infants exposed to valproate during pregnancy. The daily dose given to several of the pregnant women was very high, in comparison with earlier studies. Nine of 17 pregnant women received a daily dose of $\geqslant 2.5 \mathrm{~g}$, the highest being $6.6 \mathrm{~g}$ in the third trimester. High doses were often necessary to keep a constant plasma concentration because the free fraction of valproate increases during pregnancy with a consequent increase in renal excretion.

Contrary to other authors, we found no association between valproate treatment during pregnancy and intrauterine growth retardation ${ }^{91013}$ or severe asphyxia. ${ }^{11}$ The infants were of normal gestational age and birth weight and no infant was significantly asphyxiated at birth.

Nine $(53 \%)$ of the infants showed neurological manifestations such as irritability, jitteriness, abnormal tone, seizures, and feeding problems. These were related to the valproate dose, commenced 12 to 48 hours after delivery, and we regarded them as being due to withdrawal. The hypotonia and feeding problems may have been due to the sedative effect of valproate.

Withdrawal symptoms have not been previously described in neonates exposed to valproate during pregnancy. According to DiLiberti et $a l^{9}$ and Nau et al, ${ }^{16}$ four out of 19 infants were irritable and/or jittery. The daily valproate dose in these mothers during the third trimester varied between 0.75 and $2.0 \mathrm{~g}$. The fact that withdrawal symptoms have not been described previously might be because doses of more than $2 \cdot 0-2 \cdot 5 \mathrm{~g}$ have only very seldom been given to pregnant women. The risk of withdrawal symptoms is presumably related to the increase in the free fraction of plasma valproate during pregnancy. ${ }^{11}$

Hypoglycaemia occurred in four of the nine infants in whom blood glucose concentrations were measured. One of the infants described by DiLiberti et al also had hypoglycaemia. ${ }^{9}$ However, the risk of developing hypoglycaemia cannot be known without systematic measurements of blood glucose concentrations in all infants.

The minor abnormalities as well as the major malformations were characteristic for the fetal valproate syndrome. ${ }^{9141518}$ There was a tendency for the frequency of abnormalities and malformations to be related to the valproate dose in the first trimester. JägerRoman et al found the same tendency, ${ }^{11}$ although the highest dose they used was $2 \cdot 0 \mathrm{~g}$ per day.

Previous authors have suggested a tendency towards an increase in the frequency of abnormalities and malformations in those epileptic mothers receiving valproate as part of polytherapy rather than monotherapy. We did not confirm this.

Retarded psychomotor development occurs frequently in children of epileptic mothers treated with valproate during pregnancy, as also described by other authors. ${ }^{9} 1415$

We conclude that there is a tendency for fetal valproate syndrome, characterised by both minor abnormalities and major malformations, to be related to the dose in the first trimester, whether given as monotherapy or polytherapy. Increasing the dose during pregnancy increases the likelihood of withdrawal symptoms. We recommend as low a dose as possible to prevent seizures in the mother. As the risk of withdrawal symptoms is presumably related to the free fraction of plasma valproate, it seems appropriate to detect and maintain this fraction at a constant concentration.

The authors would like to thank physiotherapist Hanne Agerholm for participating in the neurological function testing of the infants.

1 Dieterich E, Steveling A, Lukas A, Seyfeddinipur N, Spranger J. Congenital anomalies in children of epileptic
mothers and fathers. Neuropediatrics 1980; 11: 274-83.

2 Hanson JW, Smith DW. The fetal hydantoin syndrome. f Pediatr 1975; 87: 285-90.

3 Pinder RM, Brogden RN, Speight TM, Avery GS. Sodium valproate: a review of its pharmacological properties and valproate: a review of its pharmacological properties and

4 Dalens B, Raynaud E-J, Gaulme J. Teratogenicity of valproic acid. $\mathcal{F}$ Pediatr 1980; 97: 332-3.

5 Robert E, Giubaud P. Maternal valproic acid and congenital neural tube defects. Lancet 1982; ii: 937.

6 Bjerkedal T, Czeizel A, Goujard J, et al. Valproic acid and spina bifida. Lancet 1982; ii: 1096.

7 Gomez MR. Possible teratogenicity of valproic acid. f Pediatr 1981; 98: 508-9.

8 Koch S, Jäger-Roman E, Rating D, Helge H. Possible teratogenic effect of valproate during pregnancy. $\mathfrak{F}$ Pediatr 1983; 103: 1007-8.

9 DiLiberti JH, Farndon PA, Dennis NR, Curry CJR. The fetal valproate syndrome. Am $\mathcal{F}$ Med Genet 1984; 19: 473-81.

10 Tein I, MacGregor DL. Possible valproate teratogenicity. Arch Neurol 1985; 42: 291-3.

11 Jäger-Roman E, Deich A, Jakob S, et al. Fetal growth, major malformations, and minor abnormalities in infants born to women receiving valproic acid. $\mathcal{f}$ Pediatr 1986; 108: women recei

12 Lindhout D, Schmidt D. In-utero exposure to valproate and neural tube defects. Lancet 1986; i: 1392-3.

13 Bertollini R, Källen B, Mastroiacovo $\mathbf{P}$, Robert E. Anticonvulsant drugs in monotherapy. Effect on the fetus. Eur f Epidemiol 1987; 3: 164-71.

14 Winter RM, Donnai D, Burn J, Tucker SM. Fetal valproate syndrome: is there a recognisable phenotype? $\mathcal{F}$ Med Genet 1987; 24: 692-5. 
15 Ardinger $\mathrm{HH}$, Atkin JF, Blackston RD, et al. Verification of the fetal valproate syndrome phenotype. Am $₹$ Med Genet 1988; 29: $171-85$.

16 Nau H, Rating D, Koch S, Häuser I, Helge H. Valproic acid and its metabolites: placental transfer, neonatal pharmacokinetics, transfer via mother's milk and clinical status in neonates of epileptic mothers. $\mathcal{F}$ Pharmacol Exp Ther 1981 219: 768-77.

17 Kaneko S, Otani K, Fukushima Y, et al. Teratogenicity of antiepileptic drugs: analyses of possible risk factors. Epilepsia 1988; 29: 459-67.

18 Verloes A, Frikiche A, Gremillet C, et al. Proximal phocomelia and radial aplasia in fetal valproic syndrome. Eur 7 Pediatr 1990; 149: 266-7.

19 Dandliker WB, Feigen GA. Quantification of the antigenantibody reaction by the polarization of fluorescence. Biochem Biophys Res Commun 1961; 5: 299-304.

20 Adams R, Schmidt G, Vandermark F. A micro liquid column chromatography procedure for twelve anticonvulsants and some of their metabolites. F Chromatogr 1978; 145: 1275-84.

21 Holle B, Bönnelycke K, Kemp E, Mortensen LT. Motoricperceptual development. Palsvig $\mathrm{K}$, Vedel-Petersen J, eds. Copenhagen: Porsborg M Munksgaard, 1983. 